MARCIN BROL

\title{
REGULACJE PUBLICZNE W DOBIE KRYZYSU GOSPODARCZEGO
}

\section{WSTĘP}

We współczesnej gospodarce regulacje publiczne mają zazwyczaj charakter trwały. Oznacza to, że po wprowadzeniu ich do systemu prawnego funkcjonują przez wiele kolejnych lat, bez względu na stan gospodarki. Regulacje wprowadzone w okresie wzrostu gospodarczego obowiązują również w okresie słabszej koniunktury i odwrotnie, wprowadzone w czasie kryzysu funkcjonują także w okresie wzrostu. Tego typu regulacje traktowane są zatem jako nienaruszalne „prawa nabyte", dające korzyści bądź to konsumentom, bądź też producentom lub też jednostkom sektora publicznego. Ich zakorzenienie w systemie prawnym gwarantuje ich nienaruszalność. Tymczasem część regulacji publicznych wprowadzana jest na określony czas. Są one charakterystyczne dla okresów słabszego wzrostu gospodarczego lub recesji. Regulacje takie stosowane były w przeszłości, chociażby w okresie „wielkiego kryzysu” czy „,zzoków podażowych”, ale także stosuje się je obecnie. Dotyczą one najczęściej rynków: pracy, finansowego, infrastrukturalnego i energetycznego. Po kryzysie najczęściej przestają one funkcjonować, ale zdarzyć się również może sytuacja, w której tymczasowe regulacje utrwalone zostają w systemie regulacji publicznych.

Celem niniejszej pracy jest przedstawienie, analiza i ocena skutków regulacji publicznych związanych $\mathrm{z}$ przeciwdziałaniem lub łagodzeniem objawów obecnego kryzysu gospodarczego. W pracy postawiono też tezę, iż część regulacji publicznych pomimo tymczasowego charakteru stosowana jest lub będzie w sposób ciaggły również w kolejnych fazach cyklu koniunkturalnego. W rozważaniach podjęto także próbę odpowiedzi na pytanie: czy regulacje publiczne stanowią w rzeczywistości mechanizm wspomagający powrót na ścieżkę wzrostu gospodarczego, czy też - jak twierdzą niektórzy ekonomiści postulujący deregulację - są jedynie przeszkodą na tej ścieżce? W pracy skoncentrowano się na regulacjach zapisanych 
w tzw. „planach ratunkowych”, czyli programach gospodarczych przedstawionych w Polsce, Stanach Zjednoczonych oraz Niemczech w latach 2008 i 2009. Przeanalizowano też sposób oraz potencjalne skutki ich wprowadzenia dla funkcjonowania rynku pracy oraz rynku finansowego.

\section{ISTOTA REGULACJI RYNKU}

Podstawową konsekwencją niedoskonałości rynku jest jego regulacja. Według Adama Smitha zasadniczą rolą państwa było rozwijanie silnego systemu prawnego w celu utrzymania porządku społecznego. Twierdził on jednocześnie, że rynek dostosowuje się do ludzkiej natury, wobec czego rządy powinny jak najmniej ingerować w zachodzące na rynku procesy. Wielokrotnie Smith podkreślał jednak, iż dla funkcjonowania rynku konieczne są: solidny system prawa, prawa własności i moralność. Wskazywał też, że bez odpowiedniej infrastruktury: dróg, kolei, kanałów, mostów i kanalizacji, funkcjonowanie gospodarki nie byłoby możliwe. Pisząc o podziale pracy, przestrzegał też przed konsekwencją funkcjonowania tego mechanizmu w warunkach braku edukacji publicznej. Podział pracy w takiej sytuacji uczyniłby z ludzi ignorantów i dyletantów ${ }^{1}$. Zatem nie można odmówić „ojcu współczesnej ekonomii” braku realizmu. Chwaląc przymioty rynku, Smith jednocześnie dostrzegał pewne jego wady i upatrywał w państwie podmiotu właściwego do utrzymania ładu i porządku.

W wieku XIX zauważono, że niektóre przedsiębiorstwa, dążąc w sposób naturalny do maksymalizacji zysku, działają wbrew interesowi publicznemu. Obserwacje te dotyczyły w głównej mierze sektora infrastrukturalnego, w szczególności kolei, a w późniejszym okresie również telekomunikacji i energetyki. W tego typu przedsiębiorstwach występują zazwyczaj bardzo wysokie koszty stałe i niskie koszty krańcowe. Utrzymanie i wytworzenie odpowiedniej infrastruktury, np. rurociągów, torów kolejowych, linii przesyłowych, jest niezwykle kosztowne, stąd wysokie koszty stałe. Natomiast gdy infrastruktura jest już wybudowana i funkcjonuje, to wtedy dostarczenie kolejnej, dodatkowej jednostki dobra kosztuje niewiele, stąd niskie koszty krańcowe. W przypadku takiego kształtowania się kosztów mamy do czynienia z monopolem naturalnym. Istotną jego cechą są zatem wysokie bariery wejścia na rynek (mówi się nawet, iż koszt wejścia na rynek jest kosztem utopionym - nie do odzyskania) oraz rosnące korzyści skali produkcji. Sytuację monopolu naturalnego uznano za przejaw zawodności rynku.

\footnotetext{
${ }^{1}$ Por. A. Aldridge, Rynek, Wydawnictwo Sic!, Warszawa 2006.
} 
W drugiej połowie XX wieku G. Stigler przedstawił inną wersję teoretycznego uogólnienia procesu regulacji ${ }^{2}$. Stworzona przez niego ekonomiczna teoria regulacji w najbardziej przekonujący sposób wyjaśnia ich sens. Teoria ta zakłada, że regulacja jest towarem, którym dysponuje państwo, i proces alokacji tego towaru będzie przebiegał zgodnie z prawem popytu i podaży. Można zatem mówić o czynnikach decydujących o wartości takiego towaru dla potencjalnych nabywców, czyli przedsiębiorstw. Regulacja jest zatem wyrazem siły aparatu państwa w gospodarce, za którą kryje się jego zdolność do poprawienia lub pogorszenia sytuacji ekonomicznej poszczególnych podmiotów gospodarczych. Stigler wskazał też korzyści i zagrożenia dla przedsiębiorstw z tytułu regulacji.

Tabela 1. Korzyści i zagrożenia regulacji z perspektywy przedsiębiorstw

\begin{tabular}{|c|c|}
\hline KORZYŚCI & ZAGROŻENIA \\
\hline $\begin{array}{l}\text { 1. Bezpośrednie subsydia i dotacje. } \\
\text { 2. Kontrola barier wejścia na rynek innych przed- } \\
\text { siębiorstw. } \\
\text { 3. Kontrola podaży dóbr substytucyjnych i kom- } \\
\text { plementarnych. } \\
\text { 4. Administracyjne ustalanie poziomu cen. }\end{array}$ & $\begin{array}{l}\text { 1. Upolitycznienie prowadzące do nierównego trakto- } \\
\text { wania poszczególnych firm (np. wzrost znaczenia firm } \\
\text { małych kosztem dużych). } \\
\text { 2. Spowolnienie procesu decyzyjnego i koszty proce- } \\
\text { dur regulacyjnych. } \\
\text { 3. Wpływ czynników pozaekonomicznych (politycz- } \\
\text { nych) na proces decyzyjny przedsiębiorstw. }\end{array}$ \\
\hline
\end{tabular}

Źródło: A. Szablewski, Teoretyczne przesłanki deregulacji gałęzi infrastrukturalnych, [w:] Studia i materiały, z. 40: Współczesna teoria ekonomii. Główne nurty i problemy, Polska Akademia Nauk, Instytut Nauk Ekonomicznych, Warszawa 1991, s. 51.

W związku z tym, że regulacje mogą mieć pozytywny, jak i negatywny wpływ na funkcjonowanie przedsiębiorstw, trudno jest jednoznacznie określić pożądane stopnie i formy regulacji. Według E. S. Savasa ${ }^{3}$ istnieje wiele pośrednich rozwiązań pomiędzy alokacją rynkową a bezpośrednim wytwarzaniem dóbr przez państwo. W kolejności od najbardziej do najmniej rynkowych rozwiązań wymienić należy: rynek - koncesje - kupony - dotowanie - umowy - sprzedaż przez państwo - porozumienia między władzami lokalnymi - bezpośrednie świadczenia państwa. Koncesje to innymi słowy pozwolenia wydawane przez regulatora (władze centralne, lokalne, instytucje nadzoru itp.). W tym przypadku sektor publiczny tworzy bariery wejścia na rynek, lecz nie wpływa na proces alokacji rynkowej ani nie ponosi bezpośrednich wydatków. Zatem koncesje lokują się w tym

${ }^{2}$ Por. G. J. Stigler, The Theory of Economic Regulation, „The Bell Journal of Economics and Management Science” 1971, vol. 2, no. 1; oraz G. J. Stigler, C. Friedland, What Can Regulators Regulate? The Case of Electricity, „Journal of Law and Economics” 1962, vol. 1-16.

${ }^{3}$ E. S. Savas, Prywatyzacja. Klucz do lepszego rzadzenia, Państwowe Wydawnictwo Ekonomiczne, Warszawa 1992, s. 99. 
zestawieniu tuż za rynkiem. Kupony, dotacje i umowy zajmują kolejne miejsca, ponieważ każda $\mathrm{z}$ tych form angażuje coraz większe wydatki sektora publicznego. We wszystkich przypadkach inicjatorem działań jest regulator, jednak w przypadku kuponów i dotacji wydatki ponosi zarówno sektor prywatny, jak i publiczny, natomiast w przypadku umów całkowita ich wartość pokrywana jest ze środków publicznych. Sprzedaż dóbr przez państwo oraz porozumienia zakładają udział w procesie wytwarzania dóbr podmiotów prywatnych. Natomiast w przypadku bezpośrednich świadczeń, czy inaczej bezpośredniego wytwarzania i dystrybucji dóbr przez państwo, mechanizm rynkowy całkowicie zastąpiony zostaje decyzjami administracyjnymi.

Spostrzeżenia Stiglera doprowadziły do powstania trendu deregulacyjnego, szczególnie widocznego w latach osiemdziesiątych i dziewięćdziesiątych XX wieku. W tym czasie nastąpiła zasadnicza zmiana w podejściu do funkcjonowania sektora publicznego, którą Osborne i Gaebler ${ }^{4}$ określili jako „sterowanie zamiast wiosłowania”. Deregulacja, czyli zmniejszenie oddziaływania instytucji regulacyjnych na gospodarkę, doprowadziła do prywatyzacji części zadań tradycyjnie przynależnych sektorowi publicznemu. Zamiast wytwarzać i dystrybuować dobra we własnym zakresie, sektor publiczny częściej zleca wykonywanie pewnych czynności jednostkom sektora prywatnego, nadzorując jedynie produkcję i dystrybucję tych dóbr. Dotyczy to zarówno dóbr prywatnych, jak i części dóbr publicznych. Współcześnie rolą instytucji regulacyjnych jest przede wszystkim przeciwdziałanie zawodnościom rynku, ale przede wszystkim poprzez wpływanie na warunki wymiany rynkowej, a nie poprzez zastąpienie wadliwych rynków państwem.

Aby wpłynąć na warunki wymiany rynkowej, konieczne jest poznanie przejawów zawodności rynku i dobranie odpowiednich do ich charakteru instrumentów regulacyjnych. Powszechnie uznano, iż przyczynami wad rynku są: zawodność konkurencji, zawodność informacji, istnienie dóbr publicznych, istnienie efektów zewnętrznych oraz niekompletność rynków. W niektórych opracowaniach za wadę rynku uznano również bezrobocie, inflację oraz ogólny brak równowagi ${ }^{5}$, jednak trudno jednoznacznie rozstrzygnąć, czy są to przejawy zawodności rynku, czy też zjawiska wynikające z cyklicznego porządku świata, a zatem wpisujące się w naturalne zachowania człowieka i będące jednocześnie elementami składowymi wszystkich procesów społecznych i ekonomicznych. Przez zawodność konkurencji należy rozumieć tworzenie się monopoli - w tym monopoli naturalnych - za pośrednictwem mechanizmu rynkowego. Zazwyczaj przyczyną powstania monopolu jest przewaga konkurencyjna po stronie jednego z uczestników rynku, po-

${ }^{4}$ D. Osborne, T. Gaebler, Rzqdzić inaczej. Jak duch przedsiębiorczości przenika i przeksztatca administracje publiczna, Wydawnictwo Media Rodzina, Poznań 1992, s. 50.

${ }^{5}$ Por. J. E. Stiglitz, Ekonomia sektora publicznego, Wydawnictwo Naukowe PWN, Warszawa 2004, s. 101. 
wodująca zdominowanie rynku przez ten właśnie podmiot. Może ona przybierać formę przewagi technologicznej - wynikającej z posiadania technologii nowocześniejszych, tańszych i bardziej wydajnych niż konkurenci, a przez to wpływającej na wytwarzanie atrakcyjniejszych dla konsumenta dóbr (np. Microsoft, Intel, Polaroid, Du Pont), lub też przewagi kosztowej - wynikającej z umiejętności wytwarzania dóbr niższym kosztem (np. monopol naturalny, chińscy producenci zabawek). Oprócz przewagi konkurencyjnej ważnym czynnikiem wpływającym na tworzenie się monopoli są bariery wejścia na rynek. Związane są one zazwyczaj z wysokimi kosztami wejścia na rynek wynikającymi z konieczności zainwestowania dużych nakładów finansowych lub też z korzyści skali, podobnie jak w przypadku monopolu naturalnego.

\section{CHARAKTERYSTYKA ZASTOSOWANYCH REGULACJ}

W dobie kryzysu naturalną konsekwencją załamania się koniunktury gospodarczej jest interwencja państwa mająca na celu przeciwdziałanie lub też łagodzenie skutków kryzysu gospodarczego. Wyrazem takiego działania są regulacje publiczne dotyczące podmiotów rynkowych, czyli konsumentów oraz producentów, lub też warunków prowadzenia takiej wymiany. Regulacje takie dotyczą zazwyczaj rynku finansowego, rynku pracy, rynku nieruchomości, rynku energetycznego oraz infrastrukturalnego. Chociaż - jak wspomniano wcześniej - brak równowagi nie powinien być uznawany za przejaw zawodności rynku, to jednak panuje ogólne społeczne przekonanie, podsycane słowami polityków, że w sytuacjach takich państwo powinno interweniować. Kryzys gospodarczy, który rozpoczął się w 2008 roku, spowodował zwiększenie zainteresowania regulacjami publicznymi, czego wyrazem były tzw. „plany ratunkowe” zaproponowane przez rządy większości krajów rozwiniętych, w tym m.in. przez USA, Wielką Brytanię i Niemcy. Zawierają one pakiet regulacji publicznych mających złagodzić skutki kryzysu. Również w Polsce podjęto próby oddziaływania na decyzje i zachowania podmiotów gospodarczych i konsumentów. Część postulowanych przez rząd regulacji wprowadzono, część z nich czeka na wprowadzenie ze względu na długotrwałe konsultacje społeczne i proces legislacyjny, z części natomiast zrezygnowano.

Pierwszą odpowiedzią na kryzys był tzw. „plan Paulsona”, który zyskał swoją nazwę dzięki jego twórcy, sekretarzowi skarbu w rządzie Busha - Paulsonowi. Zakładał on wydatkowanie 700 mld dolarów na stabilizację gospodarki, poprawę płynności finansowej banków, odzyskanie zaufania inwestorów oraz zwiększenie akcji kredytowej dla przedsiębiorstw i gospodarstw domowych. Jednak jego nadrzędnym celem było zneutralizowanie tzw. „toksycznych aktywów”. Ich pochodzenie tłumaczone było jako wynik rozrostu i pęknięcia bańki spekulacyjnej 
opartej na kredytach hipotecznych typu sub-prime, czyli wysokiego ryzyka. Brak możliwości odzyskania pożyczonych pieniędzy oraz rozwój „instrumentów pochodnych" - papierów wartościowych, których wartość jest uzależniona od wartości innych instrumentów finansowych (tzw. „instrumentów bazowych”), doprowadziły do powstania skomplikowanego i nieprzejrzystego mechanizmu, który w konsekwencji zachwiał całym globalnym sektorem finansowym. Plan ten był więc odpowiedzią na zaistniałą sytuację, w dodatku musiał być on przygotowany i wdrożony w miarę szybko, aby zapobiec ewentualnemu krachowi finansowemu i fali bankructw instytucji finansowych.

Konsekwencją kryzysu finansowego był kryzys „realny” objawiający się spadkiem konsumpcji i produkcji przy jednoczesnym wzroście bezrobocia. Odpowiedzią na zaistniałą sytuacją był kolejny plan antykryzysowy oficjalnie nazwany "American Recovery and Reinvestment Act of 2009”. Jego celem miało być:

- uratowanie i stworzenie ponad 3,5 miliona miejsc pracy w ciągu najbliższych dwóch lat;

- skomputeryzowanie Ameryki;

- zmniejszenie liczby błędów medycznych i poczynienie miliardowych oszczędności w opiece zdrowotnej;

- ożywienie sektora energii odnawialnej i dostarczenie w ciągu następnych trzech lat kapitału, w celu podwojenia krajowego potencjału odnawialnych źródeł energii;

- podjęcie największego w historii programu rewitalizacji (ang. weatherization) poprzez modernizację 75\% budynków federalnych i ponad miliona domów mieszkalnych;

- zwiększenie dostępności studiów dla siedmiu milionów nowych studentów poprzez system grantów i ulg podatkowych;

- sfinansowanie największego od 1950 roku programu budowy dróg, mostów i systemu komunikacji publicznej;

- wprowadzenie ulg podatkowych dla 129 milionów gospodarstw domowych i rozszerzenie ulgi podatkowej dla rodzin posiadających dzieci (tzw. ulgi podatkowej na dzieci);

- wprowadzenie „bezprecedensowego” poziomu przejrzystości, nadzoru i odpowiedzialności.

Na realizację planu zabezpieczono 787 mld dolarów, z czego:

- 288 mld na ulgi podatkowe;

- 144 mld na ulgi podatkowe w podatkach stanowych i lokalnych;

- 111 mld na infrastrukturę i naukę;

- 81 mld na pomoc socjalną;

- 59 mld na ochronę zdrowia;

- 53 mld na edukację i szkolenia; 
- 43 mld na energetykę;

- 8 mld na pozostałe działania 6 .

Równocześnie zaczęły powstawać analogiczne plany w innych krajach rozwiniętych. W Niemczech przyjęto pakiet ustaw zawierających podobne do amerykańskich rozwiązania. W pierwszej kolejności podjęto w tym kraju próby stabilizacji sektora finansowego, podobnie jak w Stanach Zjednoczonych. W „pakiecie finansowym" przeznaczono 400 mld euro na ratowanie zagrożonych banków, z czego 5\% tej kwoty to suma przeznaczona na zabezpieczenie gwarancji kredytowych. Dodatkowo postanowiono dokapitalizować rynek finansowy na kwotę 80 mld euro. Drugim krokiem władz niemieckich była próba pobudzenia popytu konsumpcyjnego i inwestycyjnego oraz wprowadzenie działań osłonowych o charakterze socjalnym. Do najważniejszych działań w tym zakresie zaliczyć należy:

- przeznaczenie kwoty 18 mld euro na inwestycje publiczne, w tym w infrastrukturę, szkoły, przedszkola i szkoły wyższe;

- obniżenie pierwszego progu podatkowego z 15 do 14\% od 1 lipca 2009 roku oraz wzrost kwoty wolnej od podatku docelowo w 2010 roku z 7664 euro do 8004 euro - realizacja planów podatkowych będzie kosztować w sumie 9 mld euro w ciągu dwóch lat;

- wprowadzenie dopłat do zakupu nowych samochodów - kto odda na złom co najmniej dziewięcioletnie auto, może otrzymać 2500 euro premii na zakup nowego - łączna suma wydatków na ten cel to 1,5 mld euro;

- obniżenie składek na ubezpieczenie zdrowotne o 0,6 pkt. proc. do $14,9 \%$ oraz wypłata jednorazowych zasiłków na dzieci w wysokości 100 euro 7 .

$\mathrm{W}$ porównaniu $\mathrm{z}$ przedstawionymi powyżej planami, działania polskich władz uznać należy za wyjątkowo skromne. W głównej mierze skoncentrowano się w nich na działaniach osłonowych rynku pracy oraz o charakterze socjalnym. W Ustawie z dnia 1 lipca 2009 roku o łagodzeniu skutków kryzysu ekonomicznego dla pracowników i przedsiębiorców ${ }^{8}$ oraz „Planie stabilności i rozwoju” ${ }^{\text {za- }}$ pisano m.in.:

- dopłaty do wynagrodzenia pracownika;

- stypendia dla osób korzystających ze szkoleń;

- zmianę okresu rozliczeniowego czasu pracy i uelastycznienie czasu pracy;

- dopłaty do kredytów mieszkaniowych;

${ }^{6}$ American Recovery and Reinvestment Act of 2009, United States Government Printing Office, Washington, 6.01.2009.

${ }^{7}$ K. Bennhold, German Stimulus Plan Includes Tax Breaks on Cars, „The New York Times”, 5.11.2008; J. Dempsey, Germany Is Planning a Bigger Stimulus Package, „The New York Times”, 12.01.2009.

${ }^{8}$ Dz. U. 2009, nr 125, poz. 1035.

${ }^{9}$ Plan stabilności i rozwoju - wzmocnienie gospodarki Polski wobec światowego kryzysu finansowego, Ministerstwo Finansów, Warszawa 2008. 
- zwiększenie gwarancji dla depozytów bankowych.

Dodatkowo w dokumentach tych zapisano też obniżenie i uproszczenie podatków (w tym przede wszystkim wprowadzenie dwustopniowej skali PIT) oraz wykorzystanie funduszy unijnych. Działań tych nie należy jednak uznać za odpowiedź na kryzys. Były one bowiem zapowiadane już wcześniej i zostałyby zrealizowane niezależnie od globalnej sytuacji ekonomicznej. Dopisanie ich do planów antykryzysowych jest jedynie przejawem marketingu politycznego. Można też uznać, że polskie rozwiązania bazują na pomyślnej realizacji planów w innych krajach świata. Dzięki temu możliwe będzie „przeczekanie” złej koniunktury, bez wydatkowania dodatkowych środków z budżetu państwa.

\section{OCENA ZASTOSOWANYCH REGULACJ}

Zdecydowana większość zastosowanych regulacji we wszystkich $\mathrm{z}$ analizowanych planów ma charakter tymczasowy. Określono bowiem konkretne ramy czasowe ich obowiązywania. Regulacje te mają za zadanie przeciwdziałanie skutkom kryzysu, a nie jego przyczynom. Podstawowymi obszarami, w których je zastosowano, są rynek pracy oraz rynek finansowy. Wobec pierwszego nadrzędnym celem jest utrzymanie istniejących już miejsc pracy. Doprowadzić do tego ma uelastycznienie rynku oraz wspomaganie finansowe przedsiębiorstw zagrożonych koniecznością redukcji miejsc pracy. W drugim przypadku chodzi przede wszystkim o stabilizację rynku finansowego poprzez dokapitalizowanie banków i innych instytucji finansowych zagrożonych upadłością. Tym samym rządy poszczególnych krajów zabezpieczają się przed konsekwencjami fali bankructw, która mogłaby doprowadzić do straty części oszczędności ulokowanych przez swoich obywateli i przedsiębiorstwa, a także do konieczności innego, niż przewidują to zawarte umowy, sposobu spłaty zaciągniętych kredytów. Można zatem stwierdzić, iż podstawowym celem tego typu interwencji jest zapobieżenie panice i gwattownemu spadkowi zaufania do instytucji finansowych oraz odbudowa zaufania inwestorów oraz przedsiębiorstw korzystających z usług banków.

Zdecydowanie mniej miejsca poświęcono rozwiązaniom mającym na celu stymulację popytu na dobra konsumpcyjne i produkcyjne. W przeciwieństwie do dotychczas stosowanych metod przeciwdziałania skutkom kryzysu, w mniejszym stopniu położono nacisk na inwestycje infrastrukturalne. W głównej mierze powiązano działania takie $\mathrm{z}$ rozwojem nowych, energooszczędnych technologii oraz rozwojem edukacji. Chociaż kwoty przeznaczone na ten cel w planach amerykańskich i niemieckich wydają się imponujące, to jednocześnie na uwadze należy mieć fakt, iż współczesne inwestycje infrastrukturalne mają zdecydowanie mniejsze przełożenie na stymulowanie wzrostu gospodarczego, niż miało to miejsce 
w XX wieku. Przede wszystkim stało się to konsekwencją komplikacji procesów planistycznych i inwestycyjnych. Inwestycje państwowe w sferze infrastrukturalnej w przeszłości były bowiem o wiele prostsze. Współcześnie lwią część środków przeznaczanych na ten cel pochłania przygotowanie dokumentacji projektowej, środowiskowej oraz przetargowej. Tym samym uznać trzeba, iż regulacje wprowadzane w czasie wzrostu gospodarczego stoją teraz na przeszkodzie działaniom mającym kryzysowi przeciwdziałać. Regulacje te miały za zadanie poprawę bezpieczeństwa publicznego poprzez zagwarantowanie odpowiednich - bezpiecznych w użytkowaniu, materiałów budowlanych oraz wprowadzenie kompleksowego nadzoru budowlanego. Miały także wymusić większą dbałość o środowisko i przeciwdziałać jego degradacji. Miały również doprowadzić do powstania przejrzystych procedur funkcjonowania sektora publicznego, a tym samym wyeliminowania korupcji i nepotyzmu. Zwiększenie „wrażliwości” na elementy społeczne i środowiskowe, przejrzystości oraz wprowadzenie ścisłych procedur, czyli w praktyce zwiększenie biurokracji w administracji publicznej, podwyższyło także koszt jej funkcjonowania. Tym samym wydatki publiczne liczone jako procent PKB zwiększyły się w okresie od początku do końca XX wieku około czterokrot$n^{10}{ }^{10} . Z$ pieniędzy przeznaczonych na stymulację gospodarki poprzez inwestycje publiczne znaczna część trafia zatem na utrzymanie biurokracji. Podstawowym działaniem, które powinno towarzyszyć wdrażanym planom antykryzysowym, musi być zmiana istniejących regulacji ograniczających impulsy pobudzające gospodarkę. Kolejną cechą charakterystyczną analizowanych planów jest wzmocnienie potencjału naukowego i rozwojowego poprzez powiązanie finansowania inwestycji publicznych $z$ finansowaniem badań naukowych. Jest to podyktowane najprawdopodobniej chęcią budowania gospodarki opartej na wiedzy i przekonaniem, iż w krajach rozwiniętych produkcja przemysłowa będzie miała coraz mniejsze znaczenie, a podstawową ich domeną będzie „produkcja” wiedzy. Istnieje wiele opracowań wskazujących na takie możliwości ${ }^{11}$, lecz jednocześnie wskazuje się w nich, iż proces ten ma charakter długoterminowy. Zatem działania te, jeśli doprowadzą do zamierzonego efektu, przyniosą rezultaty w odległej przyszłości. Ze wszystkich zaproponowanych do tej pory regulacji jedynie te powinny mieć zatem charakter długookresowy.

Charakteru takiego nie powinny mieć z całą pewnością ulgi i zwolnienia podatkowe stosowane na szeroką skalę, w szczególności w Stanach Zjednoczonych. Są to działania o charakterze socjalnym, mającym przynieść dodatkowe lub za-

${ }^{10}$ A. Delorme, Matériaux une comparaison internationale des dépenses publiques en lonque période, SEEI, 1983, cyt. za: D. Cohen, Ktopoty dobrobytu, Znak, Kraków 1998, s. 31-32.

${ }^{11}$ Por. A. H. Toffler, Budowa nowej cywilizacji, Wydawnictwo Zysk i s-ka, Poznań 1996; L. Edvinsson, M. S. Malone, Kapitat intelektualny, Wydawnictwo Naukowe PWN, Warszawa 2001; W. Welfe, Gospodarka oparta na wiedzy, PWE, Warszawa 2007. 
stępcze (w stosunku do utraconej pracy) źródło dochodów gospodarstwom domowym. $Z$ całą pewnością nie można ich uznać za regulacje mające na celu stymulowanie popytu konsumpcyjnego, ponieważ w wymiarze indywidualnym kwoty uzyskane w ten sposób nie stanowią istotnego czynnika powodującego wzrost konsumpcji. Jak szacuje amerykański rząd, z ulg takich skorzysta 129 milionów gospodarstw domowych, co uznać należy za dane przesadzone, gdyż liczba ludności tego kraju przekracza nieznacznie $300 \mathrm{mln}$ osób ${ }^{12}$. Oznaczałoby to, iż w praktyce każde gospodarstwo domowe skorzystałoby z przedstawionych rozwiązań. Dodatkowo dane te stają się mocno wątpliwe, jeśli wziąć pod uwagę założenia mówiące o stworzeniu około 3,5 mln nowych miejsc pracy, co automatycznie doprowadziłoby do zmniejszenia grona odbiorców tego typu pomocy. Dane dotyczące liczby nowych miejsc pracy również uznać należy za dalece niewiarygodne. Od kwietnia 2008 roku do października 2009 roku stopa bezrobocia wzrosła bowiem z 5\% do 9,8\%, a w kolejnych miesiącach z całą pewnością przekroczy $10 \%$, ponieważ od wielu miesięcy ogólna liczba miejsc pracy systematycznie maleje (np. we wrześniu 2009 roku zmniejszyła się aż o 785 tys. $)^{13}$. Dużo lepszym pomysłem wydaje się niemiecki pomysł zmniejszenia pierwszego progu podatkowego z 15\% do 14\%, przy jednoczesnym wzroście kwoty wolnej od podatku o 340 euro. Chociaż będzie to kosztować około 9 mld euro, to nie doprowadzi jednocześnie do rozrostu machiny biurokratycznej zajmującej się weryfikacją przyznawania ulg podatkowych. Dodatkowym atutem tego rozwiązania jest to, iż dotyczy ono nie tylko wszystkich gospodarstw domowych płacących podatki według tej stawki, lecz również osób fizycznych prowadzących działalność gospodarczą, czyli drobnych przedsiębiorców. Dzięki temu skala oddziaływania na popyt konsumpcyjny jest niepomiernie większa.

Zarówno w niemieckim, jak i amerykańskim planie duży nacisk położono na stabilizację rynków finansowych. Należy przyznać, iż znaczna część założeń została osiagnięta, i to już we wczesnej fazie projektu. Dokonano tego dzięki pomocy przyznanej bankom i innym instytucjom finansowym. W niektórych przypadkach pomoc była na tyle znacząca, że jej beneficjenci w praktyce zostali znacjonalizowani. Jednak dzięki tym szybkim i zdecydowanym działaniom nie dopuszczono do większej destabilizacji tego sektora i tym samym do pogłębienia kryzysu. Zasadniczą wadą planu było natomiast pominięcie kwestii zwiększenia przejrzystości rynku finansowego i usprawnienia systemu nadzoru. Wprowadzono zatem skuteczne regulacje o charakterze tymczasowym, nie proponując zmian systemowych, które zmniejszyłyby prawdopodobieństwo powstawania baniek spekulacyjnych w przyszłości. Przyczyn powstawania baniek cenowych (spekula-

\footnotetext{
${ }^{12} \mathrm{Wg}$ danych U.S. Census Bureau.

${ }^{13}$ United States Department of Labor, Bureau of Labor Statistic.
} 
cyjnych) upatrywać należy w szeregu zjawisk ekonomicznych, instytucjonalnych, kulturowych i psychologicznych. Trudno się z tym nie zgodzić, zważywszy, że ich powstanie jest zawsze efektem różnorodnych czynników, a co najważniejsze - wynikiem różnorodnego splotu ludzkich działań. Co prawda, irracjonalne zachowania drobnych, pojedynczych inwestorów nie wystarczą do stworzenia bańki cenowej, lecz rynek działa inaczej niż demokracja, stąd też duży inwestor spekulacyjny może mieć decydujący wpływ na jej powstanie. Wspólną cechą baniek cenowych jest to, iż ich źródłem są spekulacyjne działania ludzi, a te z kolei umocowane są w ludzkiej naturze. Definiowanie baniek cenowych poprzez uznanie, że zawsze wiążą się ze spekulacją, jest jednak zawodne, gdyż oznaczałoby to konieczność ich wyjaśniania poprzez empatię, czy też poznanie intencji inwestorów. Trudno zatem jednoznacznie sformułować postulaty, jakie spełniać miałyby regulacje antykryzysowe, jednak z całą pewnością powinny one mieć na względzie naturalne skłonności inwestorów do pomnażania swego majątku za wszelką cenę, bez względu na konsekwencje.

Do końca 2009 roku żadna z wprowadzonych regulacji nie zmieniła w zasadniczy sposobu funkcjonowania gospodarki rynkowej. Dotychczasowe plany i programy miały jedynie na celu przeciwdziałanie skutkom kryzysu, a nie zapobieżenie jego przyczynom. Jeśli więc w kolejnych latach regulacje takie nie pojawią się, sytuacje obserwowane w latach 90. XX wieku oraz w pierwszej dekadzie XXI wieku z całą pewnością będą się powtarzać. Chodzi tu o powstające co kilka lat bańki spekulacyjne - przede wszystkim na rynku nieruchomości oraz na giełdach papierów wartościowych (np. „bańka internetowa” w latach 1998-2000). Co więcej, przyjęte w okresie kryzysu rozwiązania oraz nabyte w tym okresie doświadczenia mogą nawet proces ten spotęgować. $Z$ wieloletnich doświadczeń i obserwacji wysnuć bowiem można wnioski, iż regulacje wprowadzane na czas kryzysu często traktowane są jako prawa nabyte, które pozostają w systemie prawnym na wiele lat. Po epoce Keynesa pozostało zatem przeświadczenie o konieczności interwencji państwa w sytuacjach kryzysowych, a po epoce Reagana przeświadczenie o konieczności prywatyzacji wszystkich rodzajów przedsiębiorstw ${ }^{14}$. Wydaje się również, że po dekadzie ciągłego wzrostu w latach dziewięćdziesiątych pozostało wśród inwestorów przekonanie o możliwości czerpania nieograniczonych zysków z działań spekulacyjnych. Regulacje wprowadzane w tych latach świadczą o przekonaniu ich autorów co do słuszności neoliberalnych postulatów dotyczących funkcjonowania rynku. W Stanach Zjednoczonych zlikwidowano w tym okresie zakaz łączenia działalności banków inwestycyjnych i kredytowych, co umożliwiło ekspansję instrumentów pochodnych. W Europie dokonano prywatyzacji sektora finansowego, bez zasadniczych zmian w sposobie sprawowania nadzoru nad

\footnotetext{
${ }^{14}$ Por. D. Osborne, T. Gaebler, Rzq̨dzić inaczej...
} 
bankami i innymi tego typu instytucjami. Przekształcenia własnościowe, choć nie doprowadziły do zmian funkcji, jaką banki pełnią w gospodarce, to wpłynęły jednocześnie na to, w jaki sposób definiują one cel swojego działania. Przedsiębiorstwa państwowe cechowały się znacznym etatyzmem oraz niższą efektywnością, lecz miały jedną zasadniczą cechę - mogły być sterowane przez rząd. Współcześnie dominującym celem każdego banku jest oczywiście maksymalizacja zysku, często bez względu na towarzyszące temu ryzyko. Nie oznacza to próby obrony własności państwowej ani próby udowodnienia przewagi tej formy nad przedsiębiorstwami prywatnymi, lecz jedynie przedstawienie zagrożeń, które wiążą się z nieodpowiedzialną prywatyzacją, tzn. taką, za którą nie idą rozwiązania prawne związane $\mathrm{z}$ nową sytuacją.

Przekonanie o konieczności ingerencji państwa w czasach kryzysu powszechne jest nie tylko wśród rządzących, lecz również wśród finansistów, którzy w rzeczywistości są współodpowiedzialni za kryzys. Co więcej, dotychczasowe działania stabilizacyjne w większości przypadków nie doprowadziły do zmian w polityce inwestycyjnej banków, a jedynie w kredytowej. Ograniczona akcja kredytowa zmniejsza możliwości rozwoju przedsiębiorczości, zmuszając jednocześnie inwestorów do kolejnych zachowań spekulacyjnych - takich jak manipulowanie kursami walutowymi w celu osiągnięcia dodatkowych zysków. Nie należy też przypuszczać, że po kryzysie zmieni się mentalność osób kierujących bankami. Wielokrotnie bowiem nagłaśniano publicznie sytuacje wypłat premii lub odpraw menedżerom bezpośrednio odpowiedzialnym za powstanie bańki spekulacyjnej, $\mathrm{w}$ dodatku ze środków publicznych przeznaczonych na ratowanie kierowanych przez nich firm. W większości przypadków nie stracili oni z tego powodu swoich stanowisk - decyzje przedsiębiorstw prywatnych są bowiem autonomiczne i w tym akurat względzie nie podlegają żadnym regulacjom.

Najważniejszą cechą planów ratunkowych zastosowanych w Stanach Zjednoczonych i Niemczech jest to, że angażują one olbrzymie sumy publicznych pieniędzy. Oznaczać to musi w konsekwencji wzrost deficytu budżetowego i spadek możliwości stymulowania wzrostu gospodarczego w kolejnych latach. Projekty przyjęte w Polsce są pod tym względem o wiele bezpieczniejsze, ponieważ angażują znacznie mniejsze środki finansowe ze źródeł publicznych. Jednak przez to sytuacja gospodarcza tego kraju zależy w większym stopniu od koniunktury na świecie niż od działań wewnętrznych. Przedłużający się kryzys wpłynie zatem negatywnie również na sytuację gospodarczą w Polsce. 


\section{ZAKOŃCZENIE}

Regulacje są z całą pewnością konieczne i niezbędne, lecz niestety te wprowadzone do tej pory nie likwidują przyczyn obecnego kryzysu. Dlatego ich efektywność w tej kwestii jest bardzo dyskusyjna. Dużo lepiej wygląda sprawa z przeciwdziałaniem skutkom kryzysu. Dzięki szybkiej i zdecydowanej reakcji państw takich jak Stany Zjednoczone i Niemcy zahamowano zawirowania na rynkach finansowych i uratowano wiele instytucji finansowych przed upadkiem, którego skutkiem mogłaby być ekspansja i pogłębienie kryzysu. Również działania mające na celu pobudzenie popytu uznać należy za pożądane. Choć w tym przypadku o wiele wyżej ocenić należy regulacje niemieckie. Bez zbędnych dodatkowych kosztów Niemcy sięgnęli po najprostsze, ale zarazem skuteczne narzędzia - obniżkę podatków, obniżkę składki zdrowotnej, podniesienie kwoty wolnej od podatku, dopłaty do zakupu nowych samochodów. Działania rządu amerykańskiego były o wiele bardziej zachowawcze, a przyjęte rozwiązania za bardzo zbiurokratyzowane. Wiele $\mathrm{z}$ postawionych celów, przede wszystkim związanych z rozwojem energii ze źródeł odnawialnych, komputeryzacją, większą dostępnością studiów i rewitalizacją, uznać należy za mało realistyczne, a ich ewentualne skutki rozłożone będą w czasie. Konsekwencją złej alokacji olbrzymich środków finansowych może być przedłużająca się stagnacja gospodarki amerykańskiej. Szczególnie, jeśli regulacje przyjęte jako tymczasowe zyskają miano wprowadzonych na stałe.

Podstawą tworzenia nowego ładu gospodarczego powinno być przeświadczenie, iż racjonalne działania pojedynczych osób (np. maklerów i graczy giełdowych) powodują nieracjonalne działania zbiorowe. Należy zatem wcześniej odpowiedzieć na szereg pytań i wątpliwości, takich jak: czy i w jaki sposób regulacje rynku finansowego mogą wpłynąć na zachowania podmiotów na nim działających? Czy regulacja rynku finansowego może odbywać się na zasadzie spisania zakazów i nakazów? I wreszcie - czy dalsze innowacje w funkcjonowaniu rynku finansowego nie będą oznaczały powstawania kolejnych niebezpieczeństw?

\section{PUBLIC REGULATIONS IN THE AGE OF ECONOMIC CRISIS}

SUMMARY

The aim of this paper is to present and evaluate public regulations proposed by the American, German and Polish governments during the economic crisis. Some of the regulations relate to financial, energy and labour markets. Most of them are introduced for the short term, but some of them will probably last for many years. This paper also discusses the efficiency of the proposed regulations. 
